\title{
Acceleration of Production Natural Disinfectants from the Combination of Eco-Enzyme Domestic Organic Waste and Frangipani Flowers (Plumeria alba)
}

\author{
Made Rai Rahayu ${ }^{1 *}$, I Nengah Muliarta ${ }^{2}$, Yohanes Parlindungan Situmeang ${ }^{3}$ \\ ${ }^{1}$ Program Study of Medical Laboratory Technology, Faculty of Health Science, Bali International University, Indonesia. \\ ${ }^{2}$ Program Study of Agroecotechnology, Faculty of Agriculture, Warmadewa University, Indonesia. \\ ${ }^{3}$ Master of Agricultural Science Study Program, Postgraduate Program, Warmadewa University, Indonesia \\ *Corresponding author: rairahayu87@gmail.com
}

\begin{abstract}
Spraying disinfectants is one of the efforts to prevent the transmission of COVID-19. One of the high needs for disinfectants can be overcome by using natural disinfectants or those made from natural ingredients, such as the use of eco-enzymes. The problem is that it takes 3 months to produce an eco-enzyme, so it needs innovation to be able to produce it quickly. This research is an experimental study with independent variables, namely the composition of organic waste (rambutan fruit skin, corn cobs, chayote skin) as a substrate in varied eco-enzyme raw materials. Each treatment added $10 \%$ frangipani sandalwood extract. Control variables include fermentation time, water composition, brown sugar, yeast (Saccharomyces cerevisiae) with a fixed amount. The experimental results showed that the length of fermentation time, the alcohol concentration increased, while the $\mathrm{pH}$ value decreased. The optimum time to produce eco-enzymes according to standard requirements for disinfecting purposes is 8-10 days, wherein the fermentation has produced an alcohol content of 60-70\% and the pH of eco-enzymes has been reached below 4.0. The content of compounds in frangipani flower extract through phytochemical and GC-MS tests include terpenoids (linalool, geraniol, terpineol), quercetin from the flavonoid, and citrulline groups of alkaloids and tannins which have various activities that support their role as a natural disinfectant including antibacterial, antifungi, and antivirals. The combination of Eco-Enzym from domestic organic waste and frangipani flower (Plumeria alba) can inhibit the growth of Staphylococcus aureus bacteria with very strong inhibition category ranging from $31.85-34.41 \mathrm{~mm}$.
\end{abstract}

Keywords: disinfectant, eco-enzyme, frangipani flowers

\section{Introduction}

Nowadays, the world is suffered from a dangerous disease that can threaten all people, this disease is known as Covid-19 which is a new type of disease caused by infection with the Severe Acute Respiratory Syndrome (SARS-CoV) virus [1]. This virus can spread easily through contact with sufferers or through droplets that come out of a patient's cough or sneezing and stick to the objects such as door handles, electric sockets, and others, which are then held by other people [2] One of the preventions that can be done is spraying disinfectants.

The high demand for disinfectants during a pandemic can be solved by using eco-enzyme. The benefits of eco-enzyme are various, especially during this pandemic, it can be used as disinfectant and hand sanitizer [3]. The eco-enzyme was discovered by Dr. Rosukon from Thailand. It was the result of fermentation from a mixture of sugar, fruit waste, and water with a ratio of 1: 3: 10 [4]. This fermentation process was the result of enzyme activity contained in bacteria or fungi. It's used as a disinfectant because of the alcohol and acetic acid content in the liquid [5]. 
Eco enzymes have been introduced to replace commercial enzymes. Organic acids are the important key in determining acidity. This means that the higher the organic acid content, the lower the $\mathrm{pH}$ value is [4]. Pure waste enzymes are concluded to be acidic and do not contain ammonia nitrogen, phosphorus [6].

The process of making eco-enzymes conventionally takes 3 months for the fermentation process [7]. The long manufacturing time makes people are reluctant to use this eco-enzyme manufacturing method for household needs. The mechanism for making this eco-enzyme is through a process that is similar to bioethanol making by fermentation. In the process of making bioethanol, after the hydrolysis process, it is followed by fermentation by using the fungus Saccharomyces cerevisiae which will convert glucose to be distilled into alcohol [8]. Meanwhile, in the eco-enzyme, the fermentation process continues until a mixture of alcohol and acetic acid is produced. There have not been scientific studies yet discussing the quality of making eco-enzymes fermented with the yeast Saccharomyces cerevisiae. Based on this description, the researchers are interested in combining conventional eco-enzyme manufacturing methods and bioethanol to produce an eco-enzyme with the appropriate alcohol content and $\mathrm{pH}$ in a shorter time.

The organic waste used in making eco-enzymes in this research is corn cobs, rambutan fruit skin, and chayote skin. These three wastes were chosen because there are a lot and have high cellulose content. Besides antimicrobials needed, a good disinfectant should be environmentally friendly and have a less pungent and irritating aroma. One of the potential ingredients to overcome this is frangipani sandalwood (Plumeria alba.) extract.

Frangipani sandalwood is one of a plant that is available in every house in Bali. Frangipani sandalwood extract contains aromatic and volatile compounds with the main components found in them including linalool, geraniol, terpineol, citrulline which have antioxidant, anti-inflammatory, anti-fungal, antiviral, antibacterial, and anti-tumor properties that can be used in the health sector [9]. In addition, the compounds in frangipani are also reported to be toxic for the survival of several microorganisms such as E. coli, S. aureus, A. niger, M. luteus, P. vulgaris, C. albicans, and D. hansenii [10]. Eco-enzyme organic household waste from raw materials of rambutan skin, corn cobs, and chayote skin which is combined with frangipani sandalwood has the potential to be formulated to be an active ingredient in the making of natural disinfectants. It is expected that the natural disinfectants will be available at a cheaper price and will be available quickly.

\section{Material and Methods}

This research is a descriptive exploratory experimental study, using a completely randomized design (CRD). This research was conducted from December 2020-January 2021 at the Forensic Laboratory of Poltabes Denpasar and UPTD. Bali Provincial Health Laboratory Center.

\subsection{Production of Eco-Enzym from Rambutan Fruit Skin, Corn Cob, and Chayote Skin}

Domestic organic waste includes rambutan fruit skin, corn cobs, and chayote skin, each of which is cut into small pieces and then blended. Each of them was weighed according to the composition of Table 1, then put into a polyethylene bottle. The use of materials made of glass is avoided because it can cause the container to break due to the fermentation process.

Preparation to produce eco-enzyme begins by adding $600 \mathrm{ml}$ of distilled water to the container (fill until $60 \%$ of the container). Then add 60 grams of brown sugar (10\% of the total distilled water) and add 6 grams of the yeast of the filling (1\% of the volume of water added). The substrate that has been previously prepared is put into a container of 180 grams (30\% of the volume of distilled water) until the mixture reaches $80 \%$ of the container. After that, the container is closed 
and opened every 6 hours to release gas. In this research, alcohol content and $\mathrm{pH}$ were measured every 24 hours for 10 days [11].

Table 1

The Composition of Eco-Enzyme

\begin{tabular}{|c|c|c|c|c|c|c|}
\hline \multirow[b]{2}{*}{ Treatment } & \multicolumn{3}{|c|}{ Substrate (gram) } & \multirow[b]{2}{*}{$\begin{array}{l}\text { Distilled } \\
\text { Water }(\mathrm{ml})\end{array}$} & \multirow{2}{*}{$\begin{array}{l}\text { Brown } \\
\text { Sugar } \\
\text { (gram) }\end{array}$} & \multirow{2}{*}{$\begin{array}{l}\text { Yeast } \\
\text { (gram) }\end{array}$} \\
\hline & $\begin{array}{l}\text { Rambutan } \\
\text { Fruit Skin }\end{array}$ & $\begin{array}{l}\text { Corn } \\
\text { Cobs }\end{array}$ & $\begin{array}{l}\text { Chayote } \\
\text { Skin }\end{array}$ & & & \\
\hline $\mathrm{P} 1$ & 180 & - & - & 600 & 60 & 6 \\
\hline $\mathrm{P} 2$ & - & 180 & - & 600 & 60 & 6 \\
\hline P3 & - & - & 180 & 600 & 60 & 6 \\
\hline P4 & 60 & 60 & 60 & 600 & 60 & 6 \\
\hline
\end{tabular}

\subsection{Preparation of Frangipani Sandalwood Flower Extract}

Frangipani sandalwood flower is cleaned and then dried for 4 days. Then it is blended to produce Simplicia and then immersed in distilled water with the mass ratio of Simplicia and solvent 1:10 for 24 hours. The extract is filtered then the solvent is evaporated with a rotary vacuum evaporator to produce the crude extract. This crude extract is mixed with fermented ecoenzymes at a level of $10 \%(\mathrm{v} / \mathrm{v})$

\subsection{Phytochemical Test Procedure [12]}

Phytochemical testing was carried out to identify secondary metabolite compounds in a group of alkaloids, flavonoids, saponins, quinones, tannins, triterpenoids/steroids contained in the extract. Each secondary metabolite will be given the reagent according to its chemical group.

\subsection{Gas Chromatography-Mass Spectroscopy (GC-MS) Test Procedure}

The analytical method using GC-MS (Gas Chromatography-Mass Spectroscopy) can measure the type and content of compounds in a sample both qualitatively and quantitatively. Frangipani sandalwood extract was analyzed using Gas Chromatography-Mass Spectroscopy (GCMS) Shimadzu QP 5000. $1 \mu \mathrm{L}$ of the extract was injected into GCMS which was operated using a glass column length of $25 \mathrm{~m}$, diameter $0.25 \mathrm{~mm}$, and thickness of $0.25 \mu \mathrm{m}$ with the CP-Sil stationary phase. $5 \mathrm{CB}$ with an oven temperature between $70-270^{\circ} \mathrm{C}$ with an increased rate of $10^{\circ} \mathrm{C} /$ minute, a carrier gas of helium with a pressure of $12 \mathrm{kPa}$, a total rate of $30 \mathrm{ml} /$ minute, and a split ratio of 1:50 [13].

\subsection{The Procedure of Testing Alcohol Content}

The test for the alcohol content of the eco-enzyme for each treatment during fermentation was carried out every 24 hours using an alcohol meter. The fermented liquid is put into a $100 \mathrm{ml}$ measuring cup as much as $60 \mathrm{ml}$ and then added. Enter the alcoholmeter in order from the lowest scale range to the beaker.

\subsection{The Procedure of Testing Acidity (pH)}

The $\mathrm{pH}$ test is carried out by inserting a liquid sample from each treatment into a $20 \mathrm{~mL}$ beaker, then dipping the $\mathrm{pH}$ meter electrode into the beaker and the results will be seen on the $\mathrm{pH}$ meter screen. Before measuring the sample, the $\mathrm{pH}$ meter was calibrated using a buffer solution.

\subsection{Antibacterial Activity Test against Staphylococcus aureus Bacteria}

Staphylococcus aureus bacteria are the most important and dangerous pathogens among the genus Staphylococcus. Often resistant to various types of drugs, making it difficult to choose antimicrobials [14] and [15]. S. aureus causes various types of infections, ranging from minor skin infections, food poisoning to systemic infections [16]. S. aureus is a gram-positive bacteria that has a diameter of 0.5-1.0 $\mathrm{mm}[17]$. 
Natural disinfectant samples in each treatment were dropped into discs placed in a petri dish. One to three Ose bacterial colonies are suspended into a tube containing $5 \mathrm{ml}$ of physiological $\mathrm{NaCl}$ solution. The bacterial suspension was swab with the Citotest inoculation loops evenly on the surface of the Nutrient Broth (NB) media base medium until the entire surface was evenly closed. Furthermore, the surface of the base layer was placed in 6 discs, each treatment, and control discs according to the marked area. Then press on the edge of the sample. The medium planted with the sample was incubated at $37 \mathrm{C}$ for 18-24 hours in an inverted position. After $24 \mathrm{~h}$ incubation, inhibition rings were observed to form around the disc with calipers [18].

\section{Results and Discussion}

\subsection{Effect of Fermentation Time on Alcohol Content and pH of Eco-Enzym}

Alcohol production resulted in the fermentation on day 3, where the alcohol content for all treatments increased consistently up to day 9 (Figure 1).

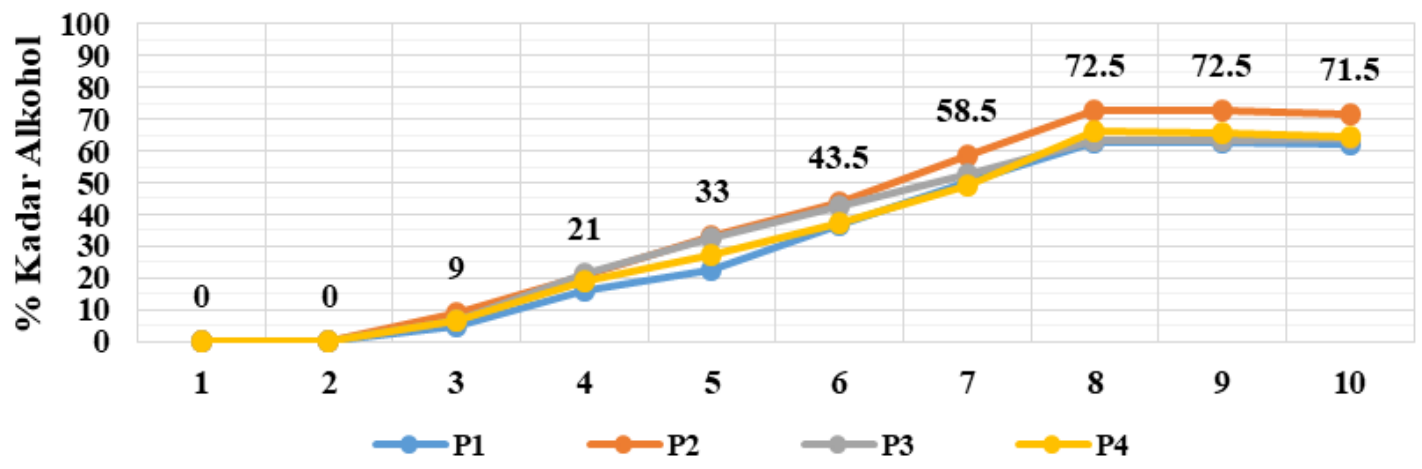

Fermentation Time (Days)

Figure 1. Graph of the percentage of alcohol content during the fermentation process

The length of fermentation time greatly affects the $\mathrm{pH}$ of eco-enzymes, because the longer it decreases. The optimum time to produce eco-enzymes according to standard requirements for disinfecting purposes is 8-10 days, in which the fermentation has produced an alcohol content of $60-70 \%$ and the $\mathrm{pH}$ of eco-enzymes has been reached below 4.0 (Figure 2). The eco-enzyme has a $\mathrm{pH}$ of about 3.5 with a BOD concentration of around $150 \mathrm{mg} / \mathrm{l}[19]$.

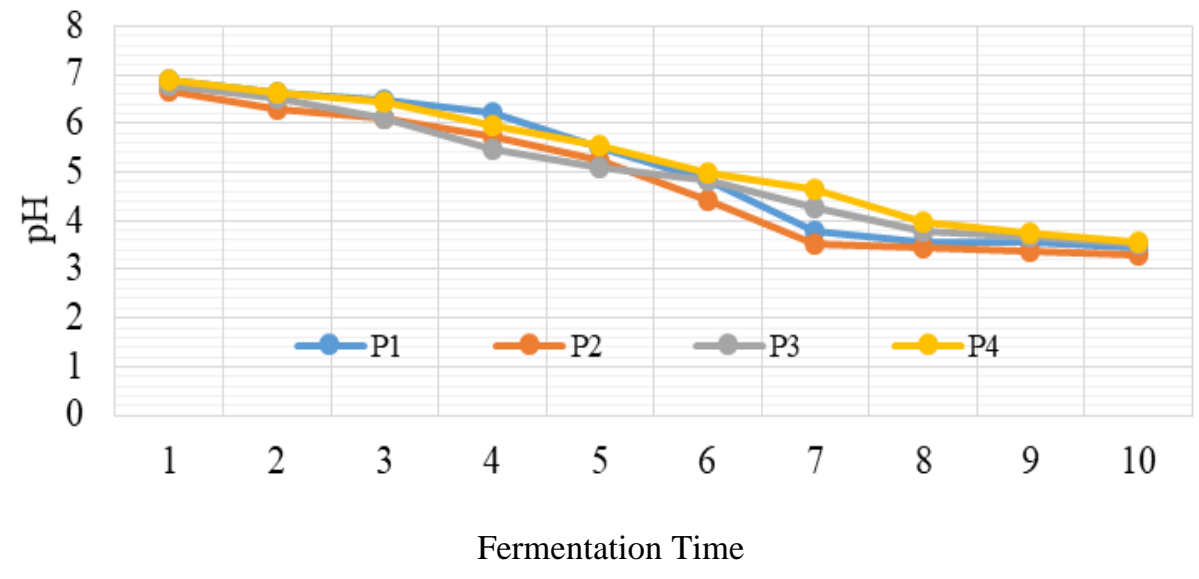

Figure 2. The relationship between $\mathrm{pH}$ Eco-Enzyme and fermentation time with 


\subsection{Compound Test of Frangipani Flower Extract (Plumeria alba)}

Based on the phytochemical testing, it can be concluded that the frangipani sandalwood extract contains secondary metabolites from the alkaloid, flavonoid, tannin/phenolic, quinone, and triterpenoid groups (Table 2).

Table 2

Phytochemical Test of Frangipani Flower Extract

\begin{tabular}{lllc}
\hline No & Chemical Group & Reaction Observation & Result \\
\hline 1 & Alkaloids & White/yellow precipitate & + \\
2 & Flavonoids & red, yellow, and orange & + \\
3 & Saponins & No stable foam is formed & - \\
4 & Tannin / Phenolic & Violet-green & + \\
5 & Quinone & Red & + \\
6 & Triterpenoids / Steroids & Orange / purple-red color & + \\
\hline
\end{tabular}

Compound content testing was also carried out using the GCMS instrument. The resulting chromatogram results are shown in the following Figure 3.

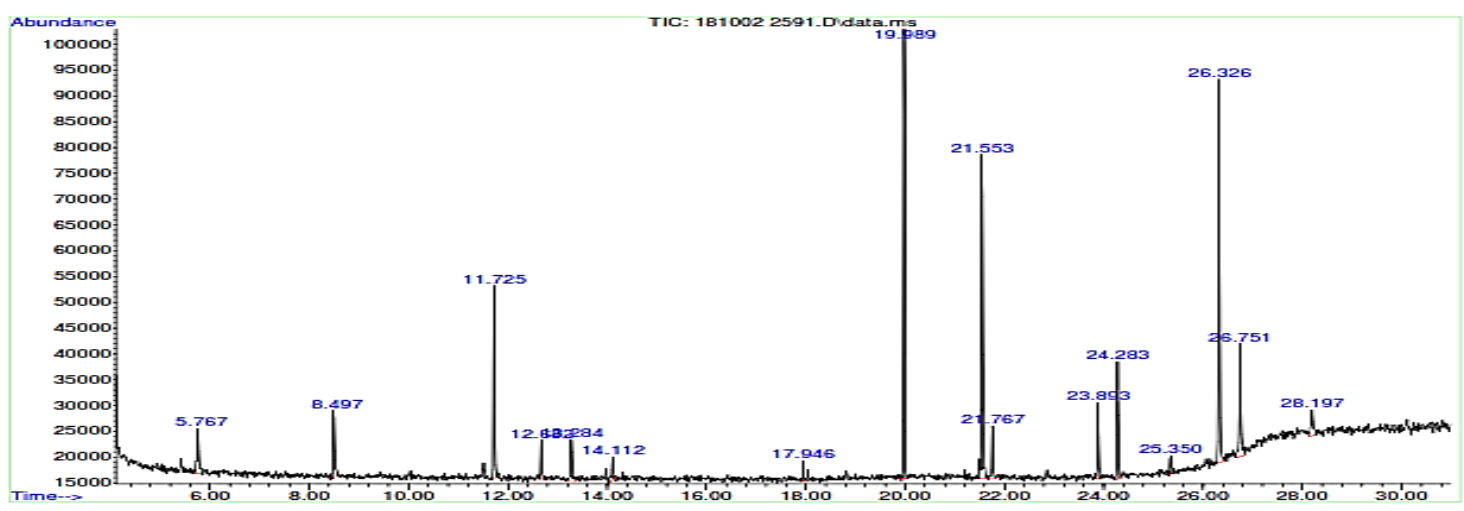

Figure 3. Chromatogram Analysis of GCMS Frangipani Flower Extract

The chromatogram above shows that there are 16 peaks identified as different compounds. Based on the identification results, the peaks with the highest abundance were shown by compounds from the carboxylic acid group including palmitic acid (19.62\%), 2-octanol palmitic (3.36\%), there were also myristic acid, lauric acid, and stearic acid with high levels of lower. Of the identified terpenoids, $\alpha$-terpineol (18.94\%), linalool (5.22\%), and geraniol (2.17\%). The flavonoid group contained was quercetin $(6.67 \%)$, while citrulline was identified from the alkaloid group with a level of $9.26 \%$.

The compound content in frangipani sandalwood extract is reported to have various activities that support its role in Bioseptan as a natural disinfectant including antibacterial, anti-fungal, and antiviral. Linalool has been reported to be able to kill influenza strains via RNA destruction mechanisms [20]. This compound also has broad antibacterial activity against E. coli, Pseudomonas aeruginosa, Staphylococcus aureus [21].

Apart from linalool, frangipani sandalwood extract contains secondary metabolite compounds in the form of alkaloids, flavonoids, tannins, quinones, and triterpenoids which are known based on the phytochemical tests carried out. These compounds have the following antibacterial activity mechanisms. The mechanism of action of flavonoids as antimicrobials can be divided into 3 , namely inhibiting nucleic acid synthesis, inhibiting cell membrane function, and inhibiting energy metabolism. The mechanism of action of tannins as an antibacterial is to inhibit the reverse transcriptase enzyme and DNA topoisomerase so that bacterial cells cannot form. Tannins have antibacterial activity related to their ability to activate microbial cell adhesion, activate enzymes, and interfere with protein transport in the inner layer of cells [12]. 


\subsection{Natural disinfectant antibacterial activity against Staphylococcus aureus bacteria}

The effectiveness test of natural disinfectants as an antiseptic was carried out by testing the Staphylococcus aureus bacteria, the results of the inhibition test are shown in Table 4.

Table 4

The inhibition against Staphylococcus aureus bacteria

\begin{tabular}{lllllll}
\hline Repetition & \multicolumn{7}{l}{ Zone of Inhibition $(\mathbf{m m})$ against Staphylococcus aureus } \\
& P1 & P2 & P3 & P4 & K(-) & K(+) \\
\hline U1 & 33,69 & 34,27 & 33,11 & 30,93 & 0 & 24,1 \\
U2 & 30,89 & 32,86 & 35,7 & 32,76 & 0 & 23,34 \\
Average & 32,29 & 33,57 & 34,41 & 31,85 & 0 & 23,72 \\
\hline
\end{tabular}

Description of the category of bacterial inhibition according to Davis Stout (2015):

Inhibition Diameter $>20 \mathrm{~mm} \quad=$ Very strong

Inhibition Diameter 10-20 $\mathrm{mm}=$ Strong

Inhibition Diameter 5-10 $\mathrm{mm}=$ Medium

Diameter of inhibition $<5 \quad=$ Weak

Based on the table above, it is known that natural disinfectants have antibacterial activity against Staphylococcus aureus bacteria with a very strong inhibition category ranging from 31.85-34.41 $\mathrm{mm}$. The inhibition power of natural disinfectants is higher than the inhibition of positive control antibiotics (Amoxicillin) which is an average of $23.72 \mathrm{~mm}$.

\section{Conclusion}

The longer the fermentation time of eco-enzymes with the help of the yeast Saccharomyces cerevisiae, the resulting alcohol content increases, while the $\mathrm{pH}$ value decreases. The optimum time to produce eco-enzymes according to standard requirements for disinfecting purposes is 8-10 days, wherein the fermentation has produced an alcohol content of $60-70 \%$ and the $\mathrm{pH}$ of eco-enzymes has been reached below 4.0.

The content of compounds in frangipani flower extract through phytochemical and GC-MS tests include terpenoids (linalool, geraniol, terpineol), quercetin from the flavonoid and citrulline groups of alkaloids and tannins which have various activities that support their role in Bioseptan as a natural disinfectant including antibacterial, anti-fungi, and antivirals.

The combination of Eco-Enzyme from domestic organic waste and frangipani flower (Plumeria alba) can inhibit the growth of Staphylococcus aureus bacteria with a very strong inhibition category. The inhibition power ranges from $31.85-34.41 \mathrm{~mm}$, so it is very potential to be used as a natural disinfectant.

\section{Acknowledgments}

Our gratitude goes to Mr. I Gusti Ngurah Wijaya, M.Si. (Forensic Laboratory of Poltabes Denpasar) for assisting in GC-MS test in the analysis of frangipani extract compounds. We would like to convey the same words to Mr. I Made Birnawan, S.Si. (UPTD Bali Provincial Health Laboratory Center.) for their contribution in assisting antibacterial testing.

\section{References}

[1] Mona, Nailul, 2020. Konsep Isolasi Dalam Jaringan Sosial Untuk Meminimalisasi Efek Contagious (Kasus Penyebaran Virus Corona Di Indonesia). Tersedia pada http://journal.vokasi.ui.ac.id/index.php/jsht/article/view/86/57 . Diakses pada 3 Januari 2021. 
[2] Lukitaningsih, Endang, 2020. Cara Penggunaan Disinfektan yang Tepat untuk Mencegah Penyebaran Covid-19. Tersedia pada https://farmasi.ugm.ac.id/id/cara-penggunaan-disinfektan-yang-tepat-untukmencegah-penyebaran-covid-19 . Diakses pada 3 Desember 2020

[3] Alkadri, S.P.S dan Asmara, K.D. 2020. Pelatihan Pembuatan Eco-Enzyme Sebagai Hand sanitizer dan Desinfektan Pada Masyarakat Dusun Margo Sari Desa Rasau Jaya Tiga Dalam Upaya Mewujudkan Desa Mandiri Tangguh Covid-19 Berbasis Eco-Community. Buletin Al-Ribaath 17 (2020) : 98-103

[4] Rasit, N., Fern, L.H., and Ghani, W.A.W.A.K. 2019. Production and Characterization of Eco Enzyme Produced From Tomato and Orange Wastes and Its Influence on The Aquaculture Sludge. International Journal of Civil Engineering and Technology (IJCIET), 10 (03): 967-980.

[5] Larasati, D., Astuti, A.P., Maharani, E.T. 2020. Uji Organoleptik Produk Eco-Enzyme dari Limbah Kulit Buah (Studi Kasus di Kota Semarang). Seminar Nasional Edusainstek, FMIPA UNIMUS 2020 : 278-283.

[6] Verma, D., Singh, A.N. and Shukl, A.K. 2019. Use of Garbage Enzyme For Treatment of Waste Water. International Journal of Scientific Research and Review, 7 (7): 201-205.

[7] Janarthanan, M., Mani, K., Raja, S.R.S. 2020. Purification of Contaminated Water Using Eco Enzyme. IOP Conf. Series: Materials Science and Engineering 955 (2020) 012098. doi:10.1088/1757899X/955/1/012098

[8] Khaira, Zul Fadly, Elvi Yenie, Sri Rezeki Muria. 2015. Pembuatan Bioetanol Dari Limbah Tongkol Jagung Menggunakan Proses Simultaneous Sacharificatian And Fermentation (Ssf) Dengan Variasi Konsentrasi Enzim Dan Waktu Fermentasi. Jurusan Teknik Kimia, Fakultas Teknik, Universitas Riau. JOM FTEKNIK Volume 2 No. 2 Oktober 2015

[9] Widianur, F dkk. 2018. Efektivitas Bunga Kamboja Cendana Sebagai Denture Cleanser Terhadap Pertumbuhan Candida albicans pada Bahan Basis Gigi Tiruan Nilon Termoplastik. https://jurnal.unej.ac.id/index.php/JPK /article/download/7148/5174. Diakses pada 23 Desember 2020

[10] Wrasiati, LP dkk. 2011. Kandungan Senyawa Bioaktif dan Karakteristik Sensoris Ekstrak Simplisa Bunga Kamboja (Plumeria sp.). https://ojs.unud.ac.id/index.php/BIO/article/view/605. Diakses pada 25 Desember 2020

[11] Yayasan Eco-Enzym. 2020. Modul Eco-Enzym 2020. Tersedia pada www.enzymsos.com diakses pada tanggal 28 Desember 2020

[12] Harborne, J. B., 1987, Metode Fitokimia, Penuntun Cara Modern Menganalisis Tumbuhan, Penterjemah: K. Padmawinata dan I. Soediro, terbitan ke-2, Penerbit ITB, Bandung.

[13] Sparkman, O.D., Penton, Z., Fulton, G.,2011, Gas chromatography and mass spectrometry: a practical guide, Elsevier Tersedia pada https://zerowaste.id/zero-waste-lifestyle/eco-enzyme/

[14] Sulistyarsi, A., and Pribadi, N.W. 2018. Test of Antibacterial Activity of Leaf Extract Binahong (Anredera cordifolia (Ten.) Steenis) on Growth of Bacteria Staphylococcus aureus and Pseudomonas aeruginosa. Journal of Pharmaceutical Science and Medical Research, 1 (1): 26-36.

[15] Karimela, E.A., Ijong, F.G and Dien, H.A. 2017. Karakteristik Staphylococcus aureus Yang di Isolasi dari Ikan Asap Pinekuhe Hasil Olahan Tradisional Kabupaten Sangihe. JPHPI, 20 (1) :188-198.

[16] Herlina N, Fifi A, Aditia DC, Poppy DH, Qurotunnada dan Baharuddin T. 2015. Isolasi dan identifikasi Staphylococcus aureus dari susu mastitis subklinis di Tasikmalaya, Jawa Barat. Pros Sem Nas Masy Biodiv Indon. 1(3): 413-417.

[17] BSN (Badan Standardisasi Nasional). 2015. SNI 2332.9: Cara Uji Mikrobiologi - Bagian 9. Penentuan Staphylococcus aureus Pada Produk Perikanan. Jakarta (ID): Badan Standar nasional.

[18] Fakultas Farmasi Universitas Sanata Dharma, 2016. Panduan Praktikum Mikrobiologi. Tersedia pada https://www.usd.ac.id/fakultas/farmasi/f113/PanduMikroBio.pdf . Diakses pada 23 Desember 2020.

[19] Tang, F.E., and Tong, C.W. 2011. A Study of the Garbage Enzyme's Effects in Domestic Wastewater. World Academy of Science, Engineering, and Technology, 60; 1143-1148.

[20] Hwa-Jung Choi. 2018. Chemical Constituents of Essential Oils Possessing Anti-Influenza A/WS/33 Virus Activity. Osong Public Health Res Perspect. 2018 Dec; 9(6): 348-353

[21] Silva, V.A, Sousa J.P., Felipe Queiroga Sarmento Guerra, Pesoa, Freitas. 2018. Antibacterial activity of the monoterpene linalool: Alone and in association with antibiotics against bacteria of clinical importance. Tersedia pada https://www.researchgate.net/publication/284829316_Antibacterial_ activity_of_the_monoterpene_linalool_Alone_and_in_association_with_antibiotics_against_bacteria_of _clinical_importance. Diakses pada Tanggal 4 January 2021. 